\title{
The Barlaam and Josaphat Legend in the Ancient Georgian and Armenian Literatures
}

\section{F. C. Conybeare M. A.}

To cite this article: F. C. Conybeare M. A. (1896) The Barlaam and Josaphat Legend in the Ancient Georgian and Armenian Literatures, Folklore, 7:2, 101-142, DOI: 10.1080/0015587X.1896.9720349

To link to this article: http://dx.doi.org/10.1080/0015587X.1896.9720349

册 Published online: 14 Feb 2012.

Submit your article to this journal $\widetilde{ }$

Џll Article views: 1 


\section{Jfolk $=$ TLore.}

TRANSACTIONS OF THE FOLK-LORE SOCIETY.

\begin{tabular}{lll}
\hline VoL. VII.] & JUNE, 1896. & [No. II. \\
\hline
\end{tabular}

\section{THE BARLAAM AND JOSAPHAT LEGEND IN THE ANCIENT GEORGIAN AND ARMENIAN LITERATURES.}

BY F. C. CONYBEARE, MY.A.

(Read at Mecting of 19th November, 1895.)

IN the following pages I have judged it best to begin with the Gcorgian or earliest Christian form of the story. I have translated such parts of the Georgian text as have been printed in St. Petersburg by Professor Marr, and I have added a translation of what is most important in his Russian monograph on the subject.

In the next place, I publish my translation of the first half, and of the last paragraph, of the old Armenian text of the story.

In conclusion, I discuss the place and importance of these two hitherto little known texts in the history of the growth and diffusion of the saga, as it may be called. 1 must express my thanks to Mr. W. E. Morfil, of Oxford, for translating to me Professor Marr's monograph, and to Professor Margoliouth for translations of parts of the oldest Arabic text.

The following text of the Georgian version of Barlaam and Josaphat is taken from the work of Professor Marr, vor. viı. 
cultitled Mfudrost" Balavara "grusinstaja versija dusepolesnoj istorii o Varlaame i loasafe": Zapiski vostoč"ago oldülcuija impcratorskago Russkago archcologičcskago obscistz'a, tom. iii. str. 223-260.

There was a certain king of the land of India, in a place which they called Iolal, anil his nane was Iabenes. IIc was in religion a pagan and an idolator, yet of gexal conscience, peaceful, molest, and very kind to the poor. And he hal no child, wherefore he was very gricyed by reason of his childlessness. For he was very tich, and desired to leave an heir over his property. For this reawn he would pray to his gols that they would vouchsafe to him offspring; lut as for his gexls they were impotent to bencfit him, and so also was prayer lo them made in vain. Allucit (jol, who desires all men to live, because of his charity which he displayed to the poor, rouchsafed to him a son noble and forlly. Therefure Ialenes the king was filled with great joy, and called his nume Ioxlasaph, and said: "This have my gods wrought for me." And he magnified them all the more, anil called together the multitude of astrologers anil of philomophers and of magicians, in order that they might inform him what wan in sture for his son and what was his destiny. But they all spake thus : "This child will altain to a glorious kingulom such as no one has ever yet nllained to in this land of Inclis." But there was one man among them, learnel witt the wistom exceding that of all, and he said to the king : "I thut link, O King, of the greainess to which this child will attain. It is not of this worll, lut methinks that he will be a great leader of truth."

thit when the king heard these words he was filled with sorrow, and forth. will he remilved on the banishment from his land of all the servants of Christ; ancl he cent out a herall to proclaim as follows: "Thus saith Iabenes the king, if any of the Christians te found after three days, with the most awful tortures shall they all le externinated." Jut one day the king went out to survey the outside of the city and beheld two men who were servants of Ciol boing out of the city, and he said to them: "Ilow were ye so bold as not to leave my land, or did ye not hear what my herald proclaimed?" But they nniwered: "Lo, even now are we about to go forth." $\Lambda$ nd he said to thein: "Why did ye stay until now?" They answered him: "Because we needed provisions for the ruad." The king said to them: "They that are in dread of Jeath, have they not provision for the rond?" But they said to him : "If we hal fearel thee we should have hastened our going; but we have no fear of death, lecallse from death we look for peace." And the king said: "Ilow any ye this, yel at the same moment through your fear of me are departing from my terfitory?" They answered: "It is not through fear of dealh that we now lake our departure from thy land, but for the reason that we may not cive a pretext to a man who is a murderer and godless. But fear of thee hath in no wine entered our souls." And he let them go; but he gave orders that if nuy Christians should be found any more they should be burnt by fire.

Nuw the King laluenes had a certain man by name Balavari, and he was 
iservant of God, full of faith and of hope in Christ. And he was much loved by the king, because he was full of thought and prudent and a good scribe, and he was more noble than all others in the eyes of the king. But Iabenes knew not that he was a scrvant of Christ, and paid him honour above all his nobles. This Ialavari, one day as he was going along a road, saw a man lying close by who had been wounded by a wild beast; and the man was crying out, and Ialavari said to him: "What is this that has happened to thec, $O$ man, that thou cricst out?" The man told him cverything, and said: "I will lay this all before thee. I am a man clever in speech, but I was being eaten by the wild least and am deprived of my limbs. But if anyone will defend me or beat it off, I will be of use to hin in the day of trouble." But the other did not count words at all, but had pity on the man and ordered his slaves to lift him up in a litter and carry him along with himself to his house, and he com. manded the steward to take good care of the man and administer comfort to him.

But Dalavari was hated by those who worshipped idols, because they were jealous of the honour which he had at the hands of the king, who preferred him to them. And they came and said to the king: "O king, the.man in whom thou reposest confidence is not of thy faith. For if there be found any of these Christian folk, he salutes them graciously, and at this moment he neditates rebellion against thee and to seize upon thy kingdom; and whomsoever he finds exiles from thy kingdom he hastens to cherish them and treats them honourably."

- And the king said to them: "If this be not so, even as ye declare it to be, then will it be bad for you, and I will hold you responsible." But he began to prove Lalavari. Ile called that man of God before him and said: "Thou Knowest, my friend, how my spirit is allied to, and bound up with, the things of earth, and how my days have leen spent. Methinks that I hasten without purpose, and I feat lest my end approach, and I be found empty. Now, Thercfore, I am resolved that henceforth I will be reconciled with the servants of Gol, and will strive after immortal life. What then dost thou say, $O$ singleminded one, and like-minded with myself $?$ " And when the man of God heard this, his mind leaped up and he shed tears and said to him: "Live, 0 king, for crer. For instearl of that which passes, thou hast chosen that which endures and is best. Of this world the glory is nought, and as the shadow it pases away, and as the smoke it disperses. Now, then, execute thy thought, for lt is meet that by abandoning this glory which passes, thou shouldst perchase the glory which is etcrnal."

And these words were displeasing to the king, and he was filled with fury by reason thereof, but he did not reveal it to the other. Then Balavari bethought him that a trap was being laid against him because of jt. And he was sote amicted, and remained all that night slecpless. Then he remembered the nuan who was clever in specch. IIe called him to him, and said to him : "Thou hast told ne that thou healest with thy words them that are wounded." And the man answered him: "Yea, it is cren so. Ilas then anything happened to thee?" ' 
But the other said: "For this long time I have served my king, and have never secn him angry with me; for I walked in singleness of mind before him. But this day he glanced at me in anger, and methinks there is no peace between him and myself." And the wounded man said to hin : "And what quarrel has there been between him and thee?" But he answered: "I know nothing, except that he spake to me a single word, and I intimated to him what was best. And methinks that he tempted me with words and will find out everything." But the wounded man said to him : "I will heal these words with the grace of Christ and the powcr of the cross. Know thou that the king harbours an evil suspicion of thee, because he suspects guile from thee, and dreans that by thee his kingdom will be seized. Rise, then, to. morrow, and cut of the hair of thy head; and take off this raiment of thine and put on mourning, and so repair before him, and if he ask thee: "What is this?' answer him thus: 'Behold, for that because of which thou didst sum. mon me yesterday, I am ready, for I do not wish to live without thee, since I whare through thee in the good things of thy kinglom. Now it is meet for me also to have a share in the sufferings of this world, and agrecably with thy wishes, I will suffer torture with thee and be thought worthy of eternity with thec."

And the man did as the sufferer instructed him, so that the suspicion was lifted of the mind of the king, and he was irritated with the accusers of lialavarl, but Balavari was racliant with joy. And once more returned the hair of his head, and once more the envy of the princes was aroused against Balavari, and they said to the king: "O king, if thou lookest into the neck of Balavari, thou wilt see there a cross, which he worships, and our gods are ridiculous in his eyes." But the king thought that they spake falsehood; but he laid hold of him, and saw a cross of gold on his breast. Then the king taid to him: "What, O Balavari, is this error of thine?" But Balavari answered: "Ah, $O$ king, I am not in error, for from my chiluhood have I served Christ and worshipped the cross on which his hands were outstretched for our salvation. But thy service hath never been prejudiced thereby. And now since the name of Christ my God is upon me, I cannot deny his divinity; even if you cut my body in bits, or burn it with fire, yet I shall comnit my spirit into his hands." The king said to to him: "Say not so, my beloved lialavari, for thou art a man held in much honour, and supreme before nie. But If thou wilt worship my gods, I will give thee yet other cities, and I will empty niy magaxines upon thee. For thou art very dear before me. But if thou do not so, I will consume thy fesh with mighty torments, nor any more remember thy love to me."

Then the man of God, Balavari, untied his belt of gold adorned with precious stones, and he laid it before the king and said: "Even if thou shouldst cover my head with the royal dindem, still by doing me such honour thou couldst not shake my faith in Christ. And although thou consunie niy Lody in torture, thow wilt not confound me. For the blessings of heaven are greatcr than those of earth, and with them we shall be for ever gratified. But the torlures of hell are rery bitter, and with them the adversarics and the 
deniers of God shall be punished. I, $\mathrm{O}$ king, am ready for earthly tortures ; so delay not, that I may the more quickly depart to my Lord, to rest in peace for ever." But at these words the king was softened and said: "Be. loved Balavari, how hast thou deprived me of hope by disobeying my orlers. Depart from my country, that the knowledge of thee may never reach my cars. If I shall find thee again, I will not be guiltless of thy blood."

So Balavari abandoned his transitory greatness, and departed unto the Eremites to serve Christ our God.

\section{The Farable of the Man and the Elephant."}

This present life is like unto a man whom an elephant pursued in fury, and drove him into a well most terrible. And the man saw trees, upon which he held himself up. And he saw two mice, one black and one white, which were bnawing at the roots of the trees, upon which he was raised up. And he looked down into the well and he saw snakes which opened their mouths and desired to devour him. Then he looked up and saw a little honey which kept dropping from the trees. And he began to lick it up, and once more he no longer bethought him of the disaster into which he was fallen.

But the mice ate deep into the trees, and the man fell, and the elephant caught him up and threw him to the serpents. Now, then, $O$ son of the king, the elephant is the image of death, which pursues the sons of men. And the trce is this life, and the mice are days and nights, and the honey is the sweet. ness of this world, and the man is distracted by the taste for this life. Days and nights are fulfilled, and death carries him off; and in hell the serpent devours him. And this is the life of men.

\section{The Auchorite's Sustenance (Professor MLarr, page 32).}

Iolasaph said: "What is the sustenance on which ye live in the wilderness?" Ile answered: "Off the herbs of the land we subsist; but when we run short, we accept from our brethren that belicve."

\section{Balavari's Creed (page 35 of Professor Marr).}

There is one God the father, sovereign of all, crentor of heaven and of earth, our Lord Jesus Christ, and the IIoly Spirit, who proceeds from the Father. Ile is the only creator, but all else is created. Ile alone is without time, but all others are in time. Ile alone is powerful, but all they are powerless. Ile alone is sublime, but all they are low. Everything was made. by him, and without him is nothing which was made. For he is good, gracious, and patient, and a lover of mankind; and there are in store for them that obey him delights, but for the disobedient torments. The same in trinity and unity is glorified.

1 For the Georgian text, sce Marr's monograph, p. 17. 


\section{The Argument from Design (page 22 of Prolessor Miarr).}

If you see a vessel which has been made, though you do not see the maker of it, yet you believe that there was a maker. And in the same way when you sce a house, though you clo not sce the builder of it, yet your intelligence nssures you that there must be one. Now when I contemplated myself, and examined my composition, I understood that I had a creator, and that, as he liked, so he created me and shaped my form, without having consulted me. If I had been my own maker, I should have made myself with more beauty and completeness. But he who created me made me lower than some and higher than others. $\Lambda$ nd I also understood this, that he would take me out of this life without consulting me. And when I understood this, and realised the facts of our life, viz., that we can neither incrense nor diminish our stature, nor renew what has grown old, or can get back again any of our limbs which may fall off, and that ncither kings, nor braves, nor sages, nor the mighty ones can do this. $\Lambda$ nd then I saw the coming of night after day, and the courses of the firmament; and from them I gathered that all things have a creator, and that he is not like his creatures. And if he were like them, then that which happens to his creatures would also happen to him. (I knew) that, as he declares, so a thing happens, and when he decrees anything it is achieved. $\Lambda$ nd he raises again people to life, such as they were from the first. For his command is swifter than a two-edged sword and is higher than glittering lightning. Ile, if it so please him, annihilates and establishes afresh every. thing. And blessed and glorious is his name, for ever and ever, $\Lambda$ men.

\section{The Saint's Tomb (page 17 of Marr).}

There was close by them a certain man, one of the Anchorites. Ile came and laid the body along with Balavarif and then went his way into the presence of Barakia the king, and told him of what had happened. But he went off with some of the lishops and priests, he gathered up the holy relics of Iodasaph and Dalavari, and conserved them in a golden slurine, and with great honour he decorated the enint. And he built orer it a church in the name of Father, Son, and Iloly Spirit, to whom is glory for ever and ever, Amen. And whosso. crer cone hither with faith, they, even up to the present day, are healed of all their discases. And we too pray to God that by their prayers we may be rescued from the pains of hell, and may glorify God, to whom is glory and honour and worship now and always and for all etcrnity, Amen.

The oppressor was overpowered, and the evil serpent struck down by the grace of a single being.

This apocryph is preceded in the Georgian manuscript by the following notice: "At one time I came into the country" of Ethiopia, where in the library of the king of the Indians I found this book in which these decds are written." 
The title of the book in the Georgian is this: "The Wisdom of Balavari related (thkmouli) by the father Isaak, son of Sophron of Palestine."

The Georgian text is not divided into chapters, but each parable is headed thus: The first word, The second word, \&e. At the end of the manuscript from which Professor Marr published his extracts there is written the following notice by the scribe who wrote it. "In 1860, in October, on the sixth day, this book was written out by the Government Secretary Nobleman, Antony, son of Zacharia Dapkviev. The hand of the labourer is turned into dust, yet this work will remain as a treasure." The manuscript itself is copied from an older one which is still in possession of a Georgian prince, Melitaurov.

In the catalogue prepared by Zagareli of the manuscripts in the Georgian convent on Mount Athos we find the mention of more than one copy of The Wisdom of Balavari. The manuscript from which Professor Marr transcribed the extracts which we have translated is plainly a faulty one. For example, in the middle of the parable of the Man pur. sued by the Elephant some words have been dropped out; for there is in it no mention, as there is both in the Arabic and the Greek text, of the dragon at the bottom of the well. It is much to be desired, therefore, that a more complete Georgian text should be prepared and printed from older manuscripts than the very modern one which Professor Marr employed.

The Georgian text, as has been noted by Marr and also by Professor Hommel, is much nearer to the old Arabic and non-Christian text than it is to the Greek. And Marr has noticed the following points of contrast between it and the Greek. These we transcribe in brief from his valuable monograph; for he had the Georgian text before him, which we only know through his extracts and remarks concerning it.

In the Georgian, then, the Indian king commits the 
education of his son from the first to a trusted counscllor, Zandan, who in the Greek only appears later on as Zardan. It is with him that the king's son converses, when, having got permission to visit the city, he meets with men crippled, sick, and old. In the Greek, again, Barlaam is seventy years old when he mects with Josaphat; and he has been in the wilderness forty-five years, having left the world at the age of twenty-five. In the Georgian, on the other hand, Balavari had retired into the desert at the age of forty-two, and had then practised asceticism there for a period of eighteen years. So it is that when he comes before lodasaph he is a man of sixty. It is only in the Greek and not in the Georgian that we read how Barlaam first baptised Iodasaph and then gave him the Eucharist. In the Georgian, again, the king Iabenes refuses to bring victims to offer to the idols on a heathen festival; whereas according to the Greek he brings for sacrifice onc hundred and twenty oxen as well as other animals. In the Georgian we hear nothing about evil spirits, nor about the magical books of the wizard Theudas. According to the Georgian, the king, before he writes to his son about his desire to be baptised, sends ambassadors, and in the end himself sets off to visit his son. In the Greck, however, we hear nothing of these ambassadors; and Josaphat, instead of baptising his father in his own house, repairs to his father's kingdom in order to do it. Again, between the time of Iodasaph's leaving his kingdom and his mecting with Balavari, two years elapsed. During this period of two years, the Georgian tells us nothing about him; whereas in the Greek we get a very particular descrip. tion of how the royal hermit in this period visited the cottage of a poor man, and of how he practised during the whole of the time the most rigorous asceticism. In the Greek also we have explained to us the way by which lodasaph found out the cave of Barlaam and got therc.

$\Lambda$ very important proof of the close connection which there is between the Georgian and the non-Christian Arabic 
and Hebrew recensions of the tale is to be drawn from the order in which in it the parables or apologues follow one another. The Georgian order, which coincides with the order of these two recensions, is as follows: I. Parable of the Good King, divided into the two stories of the Death Trumpet and of the Four Caskets; 2. Parable of the Sower; 3. Parable of the Man pursued by the Elephant; 4. Parable of the Three Friends; 5. Parable of the Foreign King who came from another Country; 6. Parable of the Heathen King and of his Faithful Counsellor; 7. Parable of the Rich Man, and of the Poor Man's Daughter: 8. Parable of the Man and the Nightingale; 9. Parable of the Roe Deer; 10. Parable of the Young Man who had a Passionate Wife; II. Parable of the Love of Women.

It is to be noticed that in the Greek version, as also in the Armenian, these parables follow in quite a different order, viz., in the following: $2,1,8,3,4,5,6,7,9$. The tenth and eleventh parables found in the Georgian are entirely absent not only from the Greek text but from the Arabic and Hebrew recensions. From the two latter the parable of the Roe Deer is also absent, although it is found in the Greck and Armenian forms of the tale. The chro. nology of the lives of the two saints as given in the Georgian is the same as that of the non-Christian Arabic, and differs from that of the Greek form.

Professor Marr further makes these remarks about the Georgian text. In The Wisdom of Balavari the importance and the position of the parables is determined by the hermit's motive, which is simply to edify. Thus Balavari, at the first meeting with Iodasaph, tells him that before he shows him the marvellous pearl, that is, the word of truth, he must test him. And then he begins to test him by reciting parables. At first he is content to give a very simple interpretation of these; but, having prepared his hearer by a series of them, he resolves to acquaint him with the rudiments of the true faith. But 
this he does not of himself, but by the lips of the wise counsellor who is introduced in parable number six. It is only when Balavari is persuaded that Iodasaph's soul is fully prepared, it is only when the latter, in imitation of the king mentioned in the sixth parable, declares his readiness to receive the true faith at once, that a dogmatic and monitory tone begins to predominate in the parables, and that finally Balavari openly preaches the Christian religion to his pupil. Meanwhile in the Arabic, in which the allegorical clement predominates, as also in the Greek, in which it is lost under a mass of reflections, the parables occupy a casual place, and are deprived of that preparatory significance which they acquire, in the Georgian adaptation, from the preaching of the ascetic. The reflections of a dogmatic and ascetic character, which are almost absent in the Arabic, and are insignificant and bricf in the Georgian, take on a wide development in the Greck; and if we compare the tale from this standpoint as we have it in the threc languages, the importance of the Arabic is very small, and we need only regard the Greek and the Gcorgian. Still, in making this comparison it is to be noticed how many points belong exclusively to the Greck. Such are the history of the Old and New Testaments, given twice over; the proof of a divine force in Christianity; the proof that it was spread by means of a small number of humble people; the comparison of the law of the New Testament with that of Moses; the long extracts from the Scrmon on the Mount, with other citations from Matthew and Luke; all the other citations from the entire Bible and those taken from the fathers; the detailed teaching of the Trinity and of all sorts of other orthodox belicfs; the inculcation of respect for Ikons; the discussion of frec-will and clection; the cxplanation of the sacraments of baptism and of the Eucharist; the scrmon on repentance and mercy; the trealise on martyrs and confessors; the circumstantial information conccrning ascetics and monks; the proof of 
the antiquity of asceticism as, a Christian practice; the description of future rewards and punishments; the cnumeration of heathen religions and of the defects of each of them; the overthrow of idols and the refutation of heathen poets. It is in these latter sections of the Greck text that Professor Armitage Robinson recognised the early Apology for Christianity of Aristides. But of it, as of all the other voluminous teachings of the Greek, we find nothing in the Georgian; and in the Armenian similarly they are scarcely to be traced at all.

Another fact of much significance is this, that in the Georgian the proper names approach in their spelling very closely to the old Indian or Buddhist forms : e.g. Georgian Jodasaph is nearer than Josaphat to the Arabic Yudasaph and BQdAsaph of the Bombay MS. (Sanskrit Bodhisattva). So the Georgian Thedma or Thedam is nearer to the Sanskrit Devadatta than the Greek Theudas, which is a misspelling suggested by the Acts. Zandani of the Georgian is nearer to the Sanskrit Chandaka and Burmese Sanna than Zardan of the Greek. Balavari is nearer to Bihalar than Barlaam. That it is still a favourite name.in Georgian shows how popular this story has ever been in that country. Again labenes is nearer the original than Abenner, which, as Kuhn points out, is duc to biblical infuence (2 Sam. iii. 6). The Bombay text lias Ganaisar. Lastly, in Georgian, the place Bolat, where the king labenes lived, is an casy corruption of Sawilabatt of the Bombay text, Buddhist Kapilavatthu.

\section{TuE armenian Form of BarlaAm aNd Josapiat.}

The following translation has been made from a text preserved in the Bodleian codex Marsh, 438. This manuscript is an Armenian Menologion, that is to say, a collection of acts of martyrs, of homilies, and other pieces appropriatc to, 
and appointed to be read in church upon, every day in the year. The story of Baralam, as the Armenian spells it, and of Josaphat, comes at the end of this $\Lambda$ rmenian Menologion, and is probably a later addition to the main collection, which was made as carly as the ninth century. I have compared this Bodleian text with that of a similar manuscript which I lately procured from Tinis, and which is now in the British Muscum. The Bodleian codex was written in the sixtcenth century, about 1550 . That of the British Museum is dated 1603 ; but this apocryph is added in a later hand at the end of the volume. I have also compared the beginning and end of the piece with a text found in an Armenian Menologion of the year 1440, prescrved in the Library of San Lazaro, at Venice. The latter is the most ancient text that I have seen of it. An older Menologion of the thirteenth century, also preserved at Venice, does not contain this piece. $\Lambda$ notice at the end of the apocryph informs us that it was translated into $A$ rmenian by one $\Lambda$ sat, under the king Bagratuni. The Bagratuni dynasty ruled from about A.D. 850 to about ro5o, so that the $\Lambda$ rmenian version may well be as old at the tenth century; and the good and pure Armenian in which it is composed makes it probable that it was earlier rather than later. Syriac constructions, especially the use of the participle for the finite verb, frequently occur, as well as some purcly Syriac words, which are to be found in no other Armenian writing. It must therefore have been made, not from a Greck, but from a Syriac text. It probably circulated among Armenian readers as an edifying tale before it was transferred into the Menologion, in the fifteenth century; for no doubt these Buddhist saints took some time to find their way into the Christian calendar. That it was circulat. ing among the Armenians as a separate book, and that it was very popular among them, long before Barlaam and Josaphat received actual canonization, is rendered probable by the circumstance that carly in the fifteenth century a certain Armenian poet, called Arhakel Vardapet, turned it 
into prose-verse; just as, in the thirteenth century, a Spanish Jew, Ibn Khizdai, turned the non-Christian Arabic recension into a Hebrew prose-poem. Of this poem or rythmic prose recension made by Arhakel, there are manuscripts both in the Bodleian and in the British Museum. At the foot of the text I have given a few variants of the Armenian story as preserved in this poem of $\Lambda$ rhakel; but it is clear that the text which he followed was the same as that which we have in the Armenian Menologia.'

\section{The Itislory of the King of India, Jovasaphat, and of Baralam the ascetic.}

Now when it became man, the word of God chose twelve disciples who were also named apostles, and it sent them into all the world to preach the kingdom of God. And the land of India fell by lot to the Apostle Thomas, who departed thither to preach Christ. And there he worked many miracles with power of the all-holy Spirit; he built churches, and ordained priests and deacons. And he himself, having fought a good fight, died in Christ. But that land stood by the preaching of the holy apostle for a long time; yet at last idolatry once nore began to prevail ; and there rose up a king great and victorious in his might, by name $A$ bener. And he aroused persecution against the Christians; and many champions of the faith were martyred by him with all sorts of tortures, men and women, old and young, and thus won the un. fading crown from Christ our God. Now this proud king Aluener had no

1 The poem of Arakhel is found in the following codices:British Mluscum, Or. 4580;

Jodleian, Canon. Orient, isi (Colophon as follows; In the year of the Armenians 883 ( $=$ A.D. 1435) this poem was composed by Arhagel Vardapet, called Balishetzi);

biblioth. Nation., Paris, Ancien Fonds Armén. No. 133, fol. 103.144 (not consulted):

Eischmiatzin Catal. of Gharenian, Nos. 1603 and 1642 (not consulted).

The prose Armenian text is given in :-

Bodlcian, Marsh MS., 438, A.D. 1550 (This text is the one here trans. lated):

British Museum, Ilajsmavourk, from Tifis (The Barlaam and Josaphat is added at the end in an cighteenth century hand):

Venice, Ilajsmavourk of A.D. 1440 (collated at beginning and end);

Etschmiatzin Codex (Gharen Catal.), No. 1642 (not consulted); sulicd).

Diblioth. Nat., Ancien Fonds Armen. No. 89, fol. 540.552 (not con- 
offspring, but all his time he would pray to the false gods to give him offspring; but they could not give it.

Then after a long time there was born to him a son. Whereat the king rejoiced, and he made much merry-making and feasting in the temples of the idols sluring many days; for he thought that his son had been given by them, and he called his name Jovasaph. And then he brought together fifty men who were astrologers and learned, and he asked of then what was to become of this child. And they carefully examined for many days the season of the child's birth, and the omens of the signs of the Zodiac. Then they came before the king and said: "As the courses of the stars teach us concerning thy son, so we will tell thee, $O$ king. The prospcrity of the infant is not in thy kinglom, but of another higher kingdom, which is above all kingdoms of the carth." But a certain one of the astrologers said: "To me it seemeth thus, 0 king, that thy son taketh up the very doctrine of the Christians, which thou, with much persccution, hast banished from thy realm, and he will exalt it in manifold ways far above thy kingdom."

When the king heard this he was sorely grieved, and, having reflected, he devised means whereby to prescrve his son from the Christian religion. And he gave orders that they should build a palace, beautiful and sumptuous; and within it he made every provision for the child's wants, and adorned it with fair constructions. And after the child was wenned he placed it in the palace which he had built and decorated; and he assigned there slaves to wait upon him, children fair to behold and youths of maturer age. And he charged them to take care lest the child should hear any of the distressing incidents which mar this life, cither of poverty, or of pain, or of old age, or of death, or of any other distressing circumstance. But he was to be told of everything which gladdens, which is goorl and blithe and joyous; of whatsocver is fair and noble unto the eyes and heart of man, of that he was to hear from them. But if any one of his attendants should fall sick or die, they were to conceal it from him, and appoint instead others to wait upon the child; and they were to excuse the absence of their fellow slave, saying that he had been sent on a Journey into a far land by the king. And one other strict command was laid upon the slaves, that they should not let fall in the child's hearing any hint of Christ and his commandments.

All this the king did because of the words of the astrologer who said: "Thy son is to become a Christian." And so the son of the king lived and was brought up in the beautiful palace, until he reached his full age, and then the hing appointed teachers for his son from among the learned men of the country. And of these the youth learned all the use of foreign langunges; so that his tutors were amaxed at such talent in one so young, and at the subtlety of his conversation. And the king was corresponilingly pleased, and marrelled at the beauty of the child and at the swiftness of his growth. And every day the king went and saw the child and came back full of joy. And he perpetually charged the attendants not to let the child hear aught of death or of the sorrows of men upon earth. Yet since it is impossible to conceal from man the knowiledge of death, it so chanced that one day Jovasaph called to 


\section{Barlaam and Fosaphat.}

hinsclf one of the slaves whom he loved and demanded to learn of hin what there was outside yonder wall, and wherefore did the king confine him there? "If then," he said," thou wilt tell me this, I will make thee second under myself ; and will give thee everything that thou shalt ask of me." But the wise slare, sceing how shrewd was the boy's mind, began to tell him all things one by one; and also about the persecution of the Christians which his father carricd on. IIe told him also of the prophecy of the astrologers, and concern. ing the same he said to him: "Our king, thy father, hath confined thec here, that thou mayst be brought up in gladness, and he has cnjoined us on no account to acquaint thee with the cares of earth even in a single particular." ,

But when the young man heard this he made no answer; yet there sprang up in his heart the word of salvation and the consoling grace of the JIoly Spirit, opening the eyes of his understanding unto the end that he should know the true God.

And on the morrow there came to him the king, and the youth advanced to meet him; and they embraced and kissed one another and then sat down. Then the youth spake to his father thus: "My lord, the king, I have a question to ask of thee, that thou wouldst teach me, for I am beset with anxiety and distress concerning the reasons for which I am detained here."

The king said: "My child, I will do as thou wishest." But the ruler was much cast down, and after reflection he said to himself: "If I oppose his quest, perhaps the child will be all the more distressed." And he forthwith had brought round steeds, gay with gold trappings; and he caused all the strects to be decorated along which the youth would pass. And he stationed before their path singers with swect voices; and he bide everything foul and unpleasant to be removed out of view of the child. And so it was daily when the youth went out, and ronmed wherever he desired. But one day, while the king's son was on his way, his slaves who went before him were negligent and were not thinking. So that he suddenly saw two men, the one a leper and the other blind, and he wondered within himself what was the matter with them. And as they could not conceal it, they said: "These are painful discases such as beset men."

And Jovasaph said: "Will every man become thas?" And they replied : "No; but some only through ills of the flesh, and others through their horoscopes." The king's son said : "Doth man know beforehand the ills of the Aesh in store for him ?" They answered: "Tis impossible for a man to know what is in store for him; the immortal gods can alone know." Anil Jovasaph was grieved thereat, and the beauty of his face wasted, and the bloom of his features and form withered away for the secing of such unwonted sights.

And on another day when Jovasaph was going on his way he saw a whitehaired man, very aged, who walked limping upon two sticks, and his hands were palsied, and he stood there leaning on his sticks and talked with enfeebled voice. And thereat Jovasaph marvelled and asked what it was he saw. And 
they said: "IIt hath lived a long time, and is therefore grown weak in body and hath lost his strength, and so he hath no power any more in body, but hath lost his strength. And thus he hath no more any power, but is broughe low, as thou perceivest."

Jovasaph said: "What will become of him ?" And they answercd: "Death will relense him from such amlictions as are his."

Jorasaph said: "What is death?" $\Lambda$ nd they answered: "It is death which severs the spirit from the Aesh, and the flesh remains lifeless."

Jovasaph said: "Is death lord over all alike or over this man only?" And they answercel, that if death were nol to remove men, the carth would not uuffice to contain mankind. But death was to come unto all alike.

Jorasaph said: "And after how many years cometh death unto man?" Anil they answerel : "Dealh waits not upon time, but comcth upon every age suildenily, on old man and child, on the humble and great, on the rich and proot alike."

Jovasaph said: "And is if possible for anyone to escape from death?" And they suid: "No, for it must needs be that all should die."

But Jovasaph when he heard all this said: "Then bitter and bricf' is the life of this world." And after thinking upon it he desired to learn what would become of man after death. And as touching this he was daily full of care, and he took no rest, but wished to find someone who could teach him the way of salvation. But he that knoweth the heart and revealeth the secrets of men s who desireth that every man should live and come to a knowledge of the truth, hewed unto him the way of life in his most merciful loving kindncss as follows:

\section{Concerving the coming of Daralam the donk.}

And it came to past in those days there was a man learned and wise among the agerl liemiles. 1te was acquninted with God's commands, and rersed in the Old and New Teutaments, very cloquent and erudite, and his name was lbaralam. Now by the intimation of the lloly Spirit he knew alout the un of the kings and he arose and came into that city in the puise of a merchant. And haring entered the city he abode there many days, until he became known to the servant of the king's son, who full often went in and out confidentially. And the old man took him aside and unil: "Know, my lord. that I am a trader come hither from a far land, and I have a precious jewel of great price, auch as no man hath ever seen the like of. And I have desired to shew it unto thee alone, because I know thee to le a wise man and trusted by thy master, the con of the greal king. And I would fain le brought by thee lefore the king's son, that I nay thew unto him the leautiful pearl. For this peasl hath power to give sight unto the Llind, to the dumb to speak, and to the deaf to hear, to the halt to walk, and

1 The word harame, which I render " bricf," is not Armenian, but is almost certainly Syriac. 


\section{Barlaam and Fosaphat.}

to the sick in heart it giveth health." The trusty slave said to him : "I bchold in thee a wise man and of firm common sense; yet I hear thee speak foolish words. Stones and pearls of great size and vast value $I$ have seen in the homes of our kings; but such as thou spcakest of I have never either heard of nor seen. But shew it unto me, that I may see whether it be as thou sayest. Then will I instantly bring thee before the king's son, and many presents wilt thou receive from him. For I cannot say aught that is false before the lord my king."

The old man Baralam replied: "Thou didst well to say that thou hadst nerer heard or seen such a pearl; but since thou didst ask to see my precious pearl, I must tell thee that, for all its powers, it has this drawback, 'that he who is sick in spirit cannot see it. I am acquainted also with the healing art, and I see in thine eyes that thou hast not perfect health. And therefore thou canst not see the beautiful pearl. However be not obstinate, but hasten to tell thy lord, lest through thee he should forfeit this precious pearl." And the slave answered that it should be so, and said: "I will make it known concerning thee to my lord the king's son." And forthwith he went unto Jovasaph and cold him all; but he was filled with joy at the tale, and he straightway com. manded that the man should be summoned before him. And Baralam having come in Lowed low in reverence for the son of the king, who bade him be sealed, and after brief converse said to him: "Shew to me thy pearl of great price."

Baralam said : "Let thy servants quit our presence, for of a truth the pearl ecemeth a fine one to my lord the king." $\Lambda$ nd when all the slaves had gone out, Jovasaph again said: "Shew me thy pearl, that I may behold it."

Baralam answered: "'Tis not meet that I should speak aught but the truth before the king, and all I have said is true. But first I will test thy mind and will afterwards shew thee the precious pearl; for the lord and sovercign whom I worship spake thus: 'Behold a sower went out to sow; and as he sowed, there was some that fell by the wayside, and the birds of the heaven devoured it. And other seed fell on rocky ground, and because there was no moisture in the place it was dried up when the sun arose. Other fell amidst thorns and itraightway the thorns sprang up and choked it. But some fell on good soil and rich, and brought forth fruit.' And I, if I find in thy heart fruitful soil, will not delay to sow thercin and make known unto thee the great mystery. Lut if thy mind be rucky, or full of tares, or trampled on by the many, then it were better not to acquaint thee; for it is written: "Give not my holy things to dogs, neither east thy pearls before swine.' But if thou believest in my words, then I will tell thee the truth, and will also shew unto thee the pearl of great price, that with its light thou mayest be lightened, and mayest bring forth fruit an hundredfold for one."

Jovasaph said : "O vencralle old man, I have a greal desire to hear sone

I From Syriac Kisliath, defectus, deficientia. The Armenian is probally therchore a version made from Syriac.

vot. vil. 
liscourse of picly. For it is now many dajs that I am amicted in my heart 8 and I have not met with any man to reveal to me that which is in my heart. Dut if I met anyone from whom I could hear the word of salvation, the fowls of the ait should not devour it, not the beasts of the ficld trample it underfoot, nor tares atrangle it, nor its leaf be dried up. Nay rather will I welcome it and cause it to shoot up right well, and nurture it with faith, and with stcadfast hupe cause it to bear fruit. But if thou knowest of such a word hide it not from me."

IJaralam said: "IVell hast thou said my son, and as besecmeth thy majesty. For thou hast not desired to pursue these vanities, but hast only had regard unto pious hopes."

And Baralam spake these paraliles [mect and helpful].'

" $\Lambda$ certain king was sitting in his chariot; and he met with some men who wore tattered garments ; and their bodies were discoloured by frost and sun. And they cried out saying, 'We are heralds of immortal life.' When the king heard these worts of theirs, he desecnded from his chariot and saluted them: and paying them great honour he seated them near unto himself. But the king' mighly ones murmured thereal, yet did not dare to sny aught to the king. But they acruainted his brother of how the sovercign outraged the honour of the suvereignty. And there cante the king's brother and told all, but the king marle no answer.

"Now it was the curtom with this king, that whomsocrer he desired to slay" he would send unto such an one's door the messenger of death; who came and blew a trumpet and sounded a prhawm at his door. So [when it was eventide] the king ent trumpeters to the door of his brother, heralding his death. So his brother hearl the heralds of his own death, which was to be at dawn. And he rose carly," and arrayed himself in a garb of mourning, and went to the dexor of the palace, and held himself to be allogether amereed of his life. When the kIng heard that his brother was come to die, he called him lefore lim and said: ' lool, if thou wast so much affrighted at the messengers of death, who were dispatclied to thy door by thy brother whom thou lovest, against whom thou hast not sinned in any way; why then wast thou gricred nith me, lecause I honoured the messengers of my Ciol, who heralded unto me immottal happiness?' And the king honoured his brother, and clad him in royal ralment, and sent him to his home rejoicing."

\section{The Scroul Marabie of Baralam.}

"Now the same king after that caused to be made two vessels of wood 1 and he ordered the one of them to be encrusted with gold and wilver, and to be adorned

- The 13. M. Colex omits the words enclosed in brackets on this and fullow. Ing pages

- 11. M. When the brullier of the king heard the nessage rif ileath, he was mucit affighted, and made a will ngninst his death on the morrow. 
with jewcls and pearls, and to be filled with foul refuse; but the other to be encrusted with bitumen, and filled with gold and pearls and jewels of value. And he had brought into the presence of his mighty oncs the two vessels, and tajd: "Put ye a price on these." And they looked and set a price on the cold-bound vesscl, even many pieces of money, its worth as it appeared to their ejes. Dut when they opened it, there issued from it so strong a stench that all fled therefrom. But when they opened the pitch-encrusted ressel there poured forth pearls and jewels of great price. Then spake the king to his princes and said: 'It is not right to be guided by what appears to the eycs of men.' But do thou too, my son, model thyself on this wise king. For thou hast not walked in the way of these vanities; but hast become par. ticipator in the hidden blessings."

Jorasaph said: "All this hast thou spoken truly and well. But I am fain to know of thy king, concerning whom thou hast told in the parable of the sowing.

Then Baralam began to tell him all things, from the beginning of the world until Christ. But Jovasaph rose and threw himself from his throne and embraced the fect of Baralam, and said: " $O$, my father, then this was the precious pearl of great price which thou didst not wish to reveal. For when Theard thy specch, the light of God's grace instantly dawned in my heart. And If thou knowest anything further of these matters, I pray thec delay not, but tell me all."

Daralam said: "Truly said my lord and king, the pearl of great price is the hidden mystery of God, that those who believe therein may nlso be baptised."

Jorasaph said: "All that has been said by thee is true; and with upright leart I believe, and I acknowledge Jesus Christ whom thou preachest to be Cod, and make avowal of him ; but I would fain know what is baptism ?"

Baralam answered: "Baptism is the root and foundation of a holy and Aawless faith in Chrisl. Baptism sanctifies us from our sins, and is a purification of the soul from all sufferings. Baptism is a new birth for him that is born azain, by fire and spirit, as the Saviour said. For those who are baptised are Instantly made worthy of the primal honour which man had in the garden. And if they kecp their baptism in truth, they regain their pristine glory. For he that is baptised in the name of Father, Son, and IIoly Spirit, straightway there cometh down upon him the grace of the IIoly Spirit, unto his illumination, for a renewal of him in all ways, and unto his becoming a secr of God, just as before man sinned he was the inage and likeness of God. For by Luptism man becomes the adopted son of his Ileavenly Father and a brother of Christ."

Jovasaph said: "Thou hast acquainted me well and truly with all. Tcll me, thercfore, what I nust do in order that we may be saved from cternal torments, and may be made worthy of the joy which men now receive from Cod."

Daralam said: "Do thou take the scal of Christ, holy baptism; and take up his cross in repentance; and follow after the crucificd Christ who calls theo 
from darkness unto light, from death to life, from ignorance unto knowledge of his truth. For the darkncss of ignorance covers them that worship idols. For It is written : The illols of the heathen are gold and silver, the handiwork of the sons of men.' They see not, neither do they hear, and have no spech in their mouths. Like unto them shall be all who made them and worship them."

\section{Parable the Third spoken by Baralam.}

"Let those who worship idols be likened to a certain birdcatcher, who caught a little sparrow, and he was bent on killing it, when the bird gave a human cry, and said, "What profit hast thou, $O$ man, in eating me? An thou wile release me and let me go, I will tell thee three maxims, which, if thou canst kecp them in mind, will be of great value and advantage to thee for thy life." lorthwith the man wonderel greatly at the human specch of the bird and lethought him of what sort of advice it would give him. So he let it go; and the sparruw flew away and perched on a bough and then began to soar in the air, and wald to the hunter, 'This is my advice, listen and take it to heart. I'ut no trust in a vain reporl, and lament not over things that are past ; and try not 10 grasp that which thou canst not reach. If thou observe this advice, thou wilt find much joy in thy life."

"Now when the hunter began to go on his way, the sparrow tempted him to sce if the nuan observed the counsels which he gave him. And he cried out to him from the air and sald, "Woe to thee, for thy folly, $O$ man, since a grand and glorious thing hath this day bcen lost to thee. For I had in my crop a great pearl, greater than the egg of an ostrich.' When the hunter heard that he began to repent that he had let the bird go , and lifting his hand in the air he stretched it oul, and tried to take hold of it, but took hold of nothing ; and since he could not reach ll, he said: 'Come down from out of the air, and I will carry thee into my house and with greal honour relcase thec.'

"Ilut the sparrow answcred and said: "Ichold, I knew thee to be a sensc. Iess man , fur thou didst with Joy receive my advice, but of three maxims thou hast nol kept one. I told thee not to repent of the past, and behold I see thy countenance changel in colour because 1 was liberated from thy hands. And whereas I warned thee not to venture to axpire to what thou canst not reach, thou endcavourest to bring me down out of the air. I lold thee also not to trust to light worls ; and yet thou hast relied on them. For how can that be found in my lelly which is greater than my entire bulk? Thou hast not bethought thee, O foul, that I, feathers and all, am not so big as the egg cf an ostrich. llow then could there be found in me a pearl of such a size?'

" Even eo foolish as he are they that put their hope in Idols and worship the works of their own hands and think they are profited thercby. For how can the crcalure save its creator? Now for us who have faith there is one

1 Sons of men is a Syriac idiom.

- The Arabic word satim is uscd in the Armenian. 
Gol, the father of all, and one Lord, Jesus Christ (by whom are all things), and one IIoly Spirit (in whom are all things). God the Father is one, and derived from none; one and only-born is the Son, timeless, begotten of the father; one is the IIoly Spirit proceeding from the Father. And this is one substance and one nature of the all-holy Trinity. This faith in God we received from the divine scriptures; in this we were baptised and of this we make profession. Thou also, then, if thou believest and art baptised, shalt be saved; but if thou believest not thou art condemned. For all this glory of thine and the splendour which thou wearest is transitory. There is a time when thou must be driven forth from all this luxury and pomp of thine, and when thy body will be confined in a cramped and narrow sepulchre, alone, separated from all friends and comrades. And instead of all this wealth thou shalt rot and be the food of worms. But thy spirit they will shut up in the place of condemnation until the last day, when there is the resurrection of the dead. Then once more thy spirit shall enter thy body and both shall fall into the burning fire eternal. All this impends for those who die in infidelity. But if with upright heart thou listen to him that calls thee unto salvation, leave all and follow after him, and thou shalt receive eternal happiness."

\section{Fourth Parable.}

"The life of the world is to be likened to (that of) the man who, fleeing from the presence of an unicorn, in the hurry of his flight fell into a ditch wide and deep. Then he stretched out his hands and laid hold of the branch of a tree which grew on the elge of the pit. And so he set his feet firmly on the bank of the ditch, and thought himself to be safely rescued. But he looked up and saw two mice, the one white and the other black, who wcre gnawing away the branch to which he clung, and they had progressed nearly so far as to cut it asunder. And looking down he saw at the bottom of the pit a terrible dragon, out of whose mouth there issued fire, and his mouth was open waiting for the man to fall in. Then he looked down to where his feet were planted and saw there the heads of four snakes that struck at the soles of his feet. But from the tree, to the bough of which he clung, there was dropping down a little sweet honey, whereupon he forgot all the stress under which he lay and opened his mouth wide to calch that litte drop of sweet honey which distilled from the trce.

"Like unto him are all who pursue the vain things of the world. But in the unicorn we are to recognise the pattern of death, who assails every man frum his birth unto his death. But the pit of the dragon is this world, full of all erils and deadly snares. But the branch which was being gnawed through by the two mice is the lwofold duration (lit, time) of life which is being consumel and wasted by day and night, and for ever approaches the point at which it will be cut short. (The black mouse is night, and the white is day.) And the four snakes (which were at his feet) are the four natures which make up man out of four elements welded together, but which, if weakened, deal death to 
men. But the dragon, big with fire and terrible, is the belly of hell, which awaits all those who have enjoyed the good things of this life. And the drop of sweet honcy (which distillad from the lough) is the sweetness of this world (and of sins) which hinder the salvation of those who love them."

Anil Jovasaph was very pleascd at the parable spoken by the old man, and besought him to tell him another like unto it.

\section{Fifth Tarable.}

Baralam said, "Those who put their hopes in the riches of this world are like unto a certain man who had three fricnds. And the two of them he loved to excess and male much of theni, and was, readly to die rather than thwart their wishes; but the third friend he held in contempt, nor ever deigned to honour him or his wishes in the same way as theirs. But on a sudden there came to him soldiers, who arrested him in haste and set ont to take hin before the king, to whom he was decply in debt. So they came and carried him away, that he might account to the king for many thousand talents which he owed. And being hard pressed by them that suinmoned him, he sought for one of his friends to come and help him in the dread tribunal of the judge. And he went first to the first of his friends and said:

"' Dost thou know, my fricnd, how at all times I have laid down my life for you? Now then, I bescech thee, help me this day; for the king summons me:

"But the friend he most honoured answered and said: 'I cannot in anywise help thee in this matter; but I can only give thee two linen raiments for thy journey, wherein thou art not profited.'

"And when the man heard this he went to his second friend, and said: "Thou knowest me, $\mathbf{O}$ my friend and companion, how I have loved thee all the days of my life. Now therefore help me, for much trouble has come upon me to-clay.'

"Ilut his friend answered and said: "What straits are they which besct thee?'

"And he sald: "The king sunmons me, and I desire thee to share in my adversily, anil in aid me as far as the king's court, and there intercede for me.'

"Iut the other sail: "I am not at leisure to go with thee, for I have many carcs. Dut I will escort thee a little way, and then return.'

"So he, being disappointed of his two friendls, went to the third, whom he despised and whom he had never thought worthy of his full affection. And he said to him, with his face full of shame: "I have not the face to address a prajer to thee, for I have never been a sharer of thy joy. And this I remeniler to-day, jet speak boldly to thee. Yet I have never done thee any kindness, whicli thou majest remember, and help me. IIclp me, then, netely an one whom thou knowest ly aight; for sore trouble has come upon me I and from my other frienils I have received no help. So I have come to bescech thee, if thou canst help me in my trouble today, not to remember 
my former heartlessness towards thee, nor the harshness with which I have ireated thee.'

"And the other's face shewed joy, and he answered and said: 'I hold thee for a true friend, and I remember that little love which thou hadst toward me. Fear not, nor be in anywise dismayed. For I will run to the king beforehand and entreat him for thee, that he cleliver thee not into the hands of thine enemies. Be of good courage, ny friend, and grieve not.'

"Then the other repented and said: "Woe to me; what have I done? I will first weep over and lament $m y$ folly, for that I had such a tencler love for my unworthy favourites, yet never thought my friend worthy of the love which he descrved." "

Jovasaph said: "Expound me this parable."

Baralam said: "The first friend is this world's tiches, which full often work great harm. For man falls into the snare because of his wealth and possessions. And then when there comes his dying day, he is not otherwise profited thereby, except to have therefrom a linen shroud. But in the sccond friend are figured familiar fricnds, relations, and comrades. In that season, they too overlook affection shewn them in the past, and give no aid in the last day of life; but only fullow and escort one as far as the tomb; after which they return to their several cilies. But the third friend, who was set at naught, is the symbol of faith and good works; and these we know, as believing in them only, though we do not carry them out in our conduct. Fet this is that which can go before us; and when we quit this world, we win through them a vision of Gol."

Jorasaph said: "Blessings on thee from the Lord thy God, O wise man; for thou hast made my heart glad. And now as touching my sire, may God to unto him according to his good plcasure. But I cspouse the words of thy teaching. Reccive my heart; for I believe in thy true God, whom thou ecrvest and proclaimest."

\section{The Sixth Parable.}

Daralam said: "If thou thus doest, thou art like to a wisc youth, who was of a very great house and son of a nolsle father, whom his father desired to marry to a prince's daughter, who was passing fair. And forasmuch as the youth desired not to marry her to whom his father had betrothed him, he fled afar into a strange land. And there he saw a poor man, with white halr, who had an only-born daughter, who as she worked with her hands with her lips praised Cod perpetually. And when the youth saw this he enquired of the damsel: "What is thy work, $O$ woman? For I sce thee to te poor, since ly the labour of thy hands thou supplicst thy necessary wants, and thankest Cod with upright heart, as if thou wast rich.'

" But the damsel made answer and said: "I thank God for my poverty, in order that I may be deserving of riches. But I rejoice yet more, for that in myself I bchold a creature that is wholly and cntircly an Inage of Cod; 
for I own in myself no want or need. But riches and poverty are from Col, and I reckon not that a good or ill of my soul.'

"When the young man heard the words of the damsel, he straightway went back to his father and said: 'Dost thou desire nyy salvation? If so, bring me to wife the daughter of yonder white-haired old man; for I am nuch pleased with her. And he persuaded his father to bring her to him as his wife. But when the marringe took place, his white-haired father-in-law called him, and bavo him an emcrald which weighed twenty litres' and said:

" Forasmuch as it hath pleased thee, my son, to become heir of my property, take this unto thee as my dinghter's dowry."

"And he took the stone and sold it to princes, and received much money as its price, and became sevenfold richer than his father."

Jovasaph eaid: "I am much delighted with thy story, $O$ holy father, and I pray thee to tell me also the meaning of thy parable."

Baralam snid: " $\Lambda$ youth art thou, and an old man am I. And my daughter is the life of our religion, which is a lovely likeness of the arche-typal God in its holiness. And the emerald is the life eternal that passes not away; but the Iwenty litres of weight shew forth the age which never grows old of them that are Immortal. But if thou listen to my preaching, and come to know the true Cod, thou shalt be serenfold richer than thy sire in this life, and shall inherit immortal life."

Jovasnph sald, "Mty heart is rejoiced full much at thy words, $O$ holy father. But tell me also this, how old thou art and what time thou lcarnedst all thin doctrine which thou teachest."

Batalam taid: "Forty-five years I have been in the desert, continually realing the divine scriptures."

Jovasnph snid: "How snyest thou that thou art forty years old: for bchold I see thee while haired, more than if thou wert eighty years of age."

llaralam said: "I numler, all my days, more than seventy years; but I seckon not all this unto my life. For so long as I was a slave to sin, I was not alive. For he that is a slave to sin is rlead in the spirit 8 and 10 I in not count my days of death in the tale of my life."

Jorasaph and " Whence the raiment wherein ye are clad, and what is your food in the descrt?"

Ibaralam sald, "Our food is the green herb, and our drink is of the dew of heaven. Wo cal and drink in peace and calm by the command of nur Creator and there is no one who arouses cliscord among us or who is avaricious or jealous of another alont his fool. But they bring us bread from our brethren who live near and love Gud. Thus do we eat, and thank Coxt. Dut out rainent is the suckeloth of our neighbours, and skins, which protect our parched bolics. And this is our clothing in winter and summer. And thus we endure patiently a litlle time, looking unto the luminous and imperishable and dealhless food."

The word litra is used.

"The B. M. coilex has "deathless raiment," which is better. 
Jorasaph said, "Then tell me whence didst thou get the raiment thou wearest?"

Baralam said: "I procured this on loan; for it was not possible for me to come unto thee in my usual garb."

Then Jovasaph began to weep, and said: "I pray thee, holy father, snatch my person out of prison, and lead me with thee into thy solitude, for I renounce the world for good and all."

\section{The Seventh Farable.}

Baralam said: " $\Lambda$ certain hunter had reared a little kid; which, when it was grown up, eseaped from the hunter and went into the mountain, which was its natural haunt, and there it found a flock of goats and mixed therewith. But the scrvants of the hunter went out in pursuit of the kid, and found it pasturing in the midst of the goats, and they took the kid and brought it back to its place; but of the rest they slew some and cruelly wounded others. But if thou shouldst join us, the same fate will befall us at thy coming; for they will follow thee and take thee back to thy place, but us they will slay. But God, in whom thou hast believed, will do unto thee according to his good pleasure. Howerer, in the present be thou baptised and receive the seal of Christ, whereby thou art able to resist the insidious temptations of Satan. So thou undertakest all the commands and code of Christ, and may God, the giver of all Ulessings, grant thee a portion in our life, that thou shouldst come unto us and pass along with us the remaining days of our life. For this I hope in the Lord, wo that in the future we may not be divided one from another."

And Jovasaph wept and said: "If this be the will of God let it be according to his plensure. But now tell me this too, whether, if one sin after baptism and again tepent one will win remission or no?"

Daralam said: "For a man to sin is not evil; since it is written: ' $\Lambda$ s often wo thou fallest, rise up; and as often as thou pollutest thyself, wash; and as often as thou sinnest, repent.' For it is written in the prophet Isajah, who upake great things: 'Tell thou thy sins first of all, for that thou shalt be justified.' For this reason is God called merciful, a lover of man, because he is not wrath with the sinner for ever. But even up to his last breath, if he repent and confess, the merciful God will not destroy him. For he himself actually says: "I came not to call the just men, but sinners to repentance."'

And Jovasnph was greatly pleased at the old man's words, and said: "I pray thee, $O$ holy man of God, to bestow on me the baptism of Christ, and receive of me whatsocver treasures thou wilt, for I will give unto thee for the wants of the brethren."

Daralam said: "As to thy reception of holy baptism, there is nothing to prevent it. Do thous only prepare thy soul for baptism and the grace of Christ. Dut as to thy proposition that I should receive aught of thy goods, which is most befitling for a rich man to give unto a poor one or for a poor man 10 a rich ? Ilow shall I receive from thy poverty the riches of alms; for the 
humblest of my brethren is richer than thyself? For they that have wealth are not rich, but are slaves of their wealth; since with daily and restless toil they endeavour to augment their possessions.

"Know then, $O$ prince, that by reason of such things ye are not rich, but slaves and men in need of riches. But we have forgotten all carking cares concerning food and raiment; because God cares for us, as we are taught in the psalm which says : "Pour out unto the Lord thy cares, and he will feed thee.' So we are freed from the flesh and from all slavery to this world, and are made rich by our concern for Christ. But if out of thy possessions I were now to give unto $m y$ brethern, disturbing blasts would arise and fill our peaceful sails, and I should become unto them a messenger of evil. But God forbid that this should come to pass."

$\Lambda$ nd Baralam arose and began to repeat unto Jovasaph the Nicene Creed, and baptised him in the name of the Father and of the Son and of the Holy Spirit in the water of the garden, and in the same moment there came upon him the IInly Spirit. And he brought the divine offering and communicated unto him the flesh and blood of the Son of God. And he said to him : "Ilenceforth keep all the commandments of God by good works; since faith wilhout works is clead, even as works without faith are in vain."

With such precepts and teaching the old man (Baralan) instructed and informed the son of the king, and then went his way unto the monastery wherein he dwelt.

But a certain one of Jovasaph's slaves, Zard by name, said to him: "Thou knowest my lord and prince, how much the fear of the king, thy sire, weighs on us, and how he set me as above all the other servants, most intimate and trustworthy, to remain always with thec. And behold, I see this stranger entering in unto thee and continually conversing with thee, and I fear that he is teaching thee the heresy of the Christians. Now, if thy sire hear this, he will straightway take away my life and cruelly destroy me. So then give orders that he be prevented from coming in unto thee. If not, I shall inform the king thy sire of crerything."

Jovasaph said: "Bcfore thou doest anything, I ask of thee, O Zard, to comply with this wish of mine. Sit thou down outside the curtain and listen to the words of the tenching of this man, which he imparts to me. And then I will tell thee what I think in my heart."

And the other did so; and on the morrow when Baralan came in before the king's son, he again said: "Welcome to thee, $O$ holy father. Teach me still further out of thy beautiful wislom, that I may be still more firmly stablished in thy commands."

Baralum sald : "Many a time have I told thee about God and his commands. [It is befitting then for thee to love the Lord thy God with all thy heart and with all thine understanding, and to keep all his commandments, and to bear in mind his behests, and to believe that he alone is creator of all creatures. Remember also that which I told thee concerning the first man, who kept not 
the commandments of his creator, and was therefore condemned and driven out of the shadowless light. Remember also what ills have befallen mankind in the train of their first father's transgression. Nevertheless the Creator over. looked, and through his prophets he foretold the marvellous mystery of the economy of the only-begotten, and all which followed the incarnation of Christ. Remembering also his voluntary sufferings, his life-giving death, his burial for three days and his resurrection, and his glorious and miraculous ascent into heaven, look unto his second coming, and just tribunal, and impartial judgement, and requital of all according to their deserts, giving the crown to the saints and ineffable glory to the just. But adjudging also neverending tortures to the sinners, for whom is prepared Satan with the ministers of his will.]

"And again I told thee many things about justice and purity; yea and also about all evils and the vanity of the life of this world [which is a mere shadow and place of sojourning for men.]' Keep therefore all that I have told thee, and the God of peace shall abide with thee."

And when Baralam went out, Jovasaph called Zard and said: "Thou hast now heard the lore which the holy man of God taught me, and knowest how he desired to save me from the deceits of this world."

But this be said to try Zard, and see what he would say. But Zard answered:

"Since thou temptest thy servant, O Prince, I know that thou hast wholly resigned thy mind to his preaching, and treasurest in thy heart all his words. So then if this be thy resolve, and if thou art able to endure their life, be thy will done. But I will not hide this from thy sire, for I am now informed as to this preaching. For thy father raised a persecution against the Christians, and they all fled from our land."

Jovasaph said: "Ilowbeit I care not, since I am ready to die for the name of Christ."

And on the morrow when Baralam desired to leave him, Jovasaph lamented with many tears the departure of the old man from himself. But Baralam with many tears and words of confort and divine teaching, established his Inind in the true faith of Christ, and promised him this also, that they would be logether in the desert, and in the presence of Christ in life immortal. And Jovasaph said : .

"I have one request to make of thee, and it is impossible for thee to fulfil it. Give me the hair sack which thou hast worn and thy little cloak, for my soul to treasure up."

And the other took them off and gave to Jovasaph all that he asked. And the latter took them and put them on, and was more delighted with them than with his royal purple. But the blessed Baralam spake these last words of his teaching to Jovasaph :

I And about the judgenent, and second coming, and the just tribunal and just requital, of the holy crown and ineffable glory of the just ... of his will. 
"My little son, whom with travail I have born by the Gospel of Clrist, mark thee well of what sovereign thou hast donned the armour and flinch not at all from fulfilling his commands."

[But Jovasaph embraced the old man, weeping bitterly, and said :

"Who shall complete for me thy teaching, and from whom shall I gain consolation for my heart? For like a good shepherd thou foundest me a sheep gone astray. For I was lost and was found by thee in faith; I was dead and was by thee made alive in Christ. Now then send forth my soul from the prison and from the shadows of death my life."]

But Baralam bade farewell to Jovasaph, and kissed him in holy wise, giving to him the peace of Christ; and then he went his way with tears of joy to. wards the desert, glorifying Christ.

But Zard saw all this, and in particular the fasting and abstinence and prayers of Jovasaph; and he was filled with sorrow, but could not inform the king thercof. And by reason of his violent sorrow he fell sick. $\Lambda$ nd when the king asked the reason of his sickness, he said :

" Because, O my Lord, thy son has learned of the evil sect of the Christians from a trickster who entered in unto him. But we from dread of thy son could not restrain that sectary."

When the king heard that, a terror scized his heart, and he remembered how he had beforchand heard of Baralam and of his teaching. And straightway he summoned his most trusted Arashis before him, who was also learned in astrology. And he saw the colour gone from his monarch's face, and said:

"Grieve not, O prince. I do thy will and pleasure, and thy son shall deny the crafty teaching of yonder fellow. So command me to go in pursuit of IBaralam; and if I take him, I will bring him before thee, and put him in such tortures as that he will declare unto thy son to be false the doctrine which he taught him."

And at once the edict went forth from the king to close and keep all the roads of the land, and to scek out Baralam. But Arashis with his soldiers arrived in the descrt and found not Baralam; but took others of the monks, eighteen souls, and having brought them before the king, they lajd stress on then to deny Christ, and to reveal where Baralam was. But they neither revealed that nor denicd Christ. So they slew them with the sword, cighteen souls. And there was in the cily a certain whitchaired magician, Nachovr by name i to whom came $\Lambda$ rashis by night, and, having clad him in a hair sack, scnt him forth into the wilderness, in order that the soldiers coming at dawn might find him and think that he was Baralam, and take and bring him to the king. For there had been a plot laid between Nachovr and the king and Arashis, of which they alone knew, and no one else.

And on the morrow, the vixicr said to some of his soldiers: "We have heard concerning Baralam, that he daily roams about this desert. Thither go and scek him out carcfully, in order that ye may perchance find him. Then the soldiers went and scattered themselves over the face of the wilderness in quest of Baralam. And when they saw Nachovr with his white hair, and his hair 


\section{Barlaam and Fosaphat.}

shirt, they took him and brought him before the vizicr, supposing him to be Baralam.

The vizicr said to him : "Whence art thou?"

And he said: "I am one of the dwellers in the wilderness."

The vizier asked : "Of what faith art thou, a votary?"

Nachorr answered : "Of the faith of Christ."

The vizier said : "What is thy name?"

Nachovr said : "Baralam."

Then the vizier began to rejoice before the eyes of the soldiers. And he took and brought him before the king. But the king took him aside and said unto him all that he desired. And on the morrow the king took his seat on his throne, and had brought before him the wolf in sheep's clothing. And when Nachovr entered, the king said in the bearing of all the public: "Thou ant Baralam, the worker of evil."

Nachovr said : "I am Baralam, servant of the true God, who have brought thy son to believe, and made him to worship God."

And the king in the eyes of the court shewed anger, and said: "I was resolved with many tortures to slay thee ; but now will I keep thee safe, until I have asked thee questions before my wise men. And if they vanquish thee, then will I give thee honour according to thy merits." And having said this he gave him to the vizier to be cast into prison.

But Jovasaph, when he heard that Baralam was taken, began to weep and prayed God to come to his assistance. But the merciful God desired not the sorrow of Jovasaph; but by means of an angel in a dream by night revealed to him all, saying: "Thy sire hath taken Nachovr, and he is a sham offender. It is Nachovr the wizard and not Baralam. But he has disguised him as Baralam, in order to persuade thee."

Then Jovasaph arose and prayed and thanked God. And after two days the king came to Jovasaph; and he went to meet his father. But his father did not kiss him according to his custom, but passed him by as if in anger and sorrow and sat down, and then he said to his son: "What is this rumour which I hear about thee? For so much as I delighted in thy being Lorn, so much the greater sorrow have I conceived. For thou hast dis. honoured my grey hair, and art become a cause of rejoicing to mine enemics. And thou hast made me the laughing stock of my neighbours and of strangers. Jovasaph said: "Ilear, $O$ my prince, and be not angry, because no ill is done; but I have escaped from darkness and followed the true light. I have renounced devils, and have believed in the true God." Dut the king was filled with wrath and knew not what to do; but in shame and sorrow he went out wying to his son: "It was better for me that thou shouldst never have been born at all."

When the king had gone out he called the vizicr, and related to him the speech of his son. But by the advice of the vizier the king went back to his won, and said: "I have in chains thy crafty teacher Baralam ; and now I will assemble a vast crowd of all races, in order that Baralam and iny own sages 
may converse before us. Dut if Baralam is vanquished, thou wilt know that he is a quack, and by false worls perverted thee from our mighty gods."

but the God-loving and well-minded youth Jovasaph said to his father: "The will of my king be done $s$ and may God do according to his good will and pleasure."

And on the morrow a multitude was gathered together of men in the king's court. There came also Jovasaph and sat down near his father. Then the king said to his wise men: "Behold and mark ye. If ye conquer Baralam, ye shall carn great gifts from us; but if ye are vanquished by him and put me to shame, no one shall rescue you frum my hands."

But Jovasaph said: "Well and rightly hath the king spoken. I, then, will converse with my teacher." And, turning to Nachovr, who was disguised as Baralam-for he knew the truth, that he was not Baralam-he said to him :

"Ihereas thou didst find me in glory and riches, yet full of understanding of thy spech, thou didst make me deny my country's gods and worship the un. known God. And thou didst promise that I should inherit the bliss which passes not, and by such words didst thou cajole me, and draw me after thy precepts, and anger the king my father against me.

"Now, therefore, set thy life in the lalance. If thou vanquish the wise men, then I know that thy words which thou hast taught me are true, and then I will honour thee with greal glory. But if thou art ranquished by them and pultest me to thame, believe me, I will with mine own hands exact from thee the penalty of my disgrace. One by one I will cut off thy members, and give thee to eat of thy own ficsl. I will pluck out thine eyes and cut out thy tongue, and then I will cast thee out to fecd the dogs, in order that thou mayest be s warning to all charlatans not to dare to deccive the sons of kings."

When Nachovr heard this, he was scized with great fear; for he saw that he lad fallen into the pit which he had dug for others, and he bethought him what he should do. And then he made up his mind to follow the wish of Jovasaph and escape his threats, for the king could not save him from the lianils of his son. And (the more so) as it was mect for the adversary to Ixcome the vindicator of the truth, and for the dog to chase the wolves from the fold of Christ.

But when they legan to dispute one with the olher, Nachovr and the wise men, as of old Balatam the magut with balak the king; who, instead of cursing. Wlessed the people of lsracl. So then one of the philosophers rose and sajul to Nachovr: "Thou art the senseless and folly-stricken Daralam."

Nachore replicd: "I an the true servant of God, Baralaw, who taught to the son of the king the way of righteousness, to worship the living God and not devils. Ilear, $O$ mighly and autocratic $k i n g$, and all the assemiled nulti. tude: Jesus Christ, he is God of all and maker of all crealures, and there is no other God tut he. But the sons of men are deccived by the evil Satan. They have forsaken their creator and worship the works of their own hands. Now, thercfure, will I tell thee, $O$ king, concerning creation. If they declare 


\section{Barlaan and Fosaphat.}

the heaven to be God they are false. For the heavens are the work of the true God. And the heaven is of air and of fire, and is stretched out over the carth and is the screen between things seen and things unseen, between the (in)ereate and the changing. So, then, if any deem the sun and moon and stars to be gods, and so speak, they do so falsely. For they are not God, but created heings, appointed by God to subserve the world and to minister to day and night. And if again they declare water to be God, they lie. For the watcrs were made for the use of the world by God, and they are liable to be mure or to be less, and also admit of change, since they are hot or cold. And if they declare fire to be God, neither in this do they aught but lie, since fire also was made for the uses of men. It giveth light and heat, but is destroyed by water and darkness. And how are these gods, when some are more powerful than others, so that they annul each other? But if they declare man to be God, that is yet more bascless. For from man and woman is he born, and taketh on all wants and bodily affections. Then he grows old and his fashion changeth and fadeth; and after all that he is heritor of the general death : he perisheth and rolleth away. For he is placed in the tomb and decayeth there, and is turned again into the dust out of which he was taken. Ilow, then, can he that perishes and passes away be the object of worship? I pass by the (superstitions) of the IIcllenes and of the Egyptians and of the Chaldacans, who instead of the immortal God worship men and women, harlots and Sodomites, and all other kinds of evil docrs, yca, and the rat and the weasel and all sorts of vermin; and out of these godless beings they have niade gods.

"But Christians from Christ have this knowledge. For they confess the all. holy Trinity, Father, Son, and IIoly Spirit, in person and name divided, but In substance and nature, will and cnergy, in power and authority, in lordship and divinily united. And the one only-begolten, procecding from three persons In unity, was made flesh out of the Iloly Virgin Mary. The only.begotten Son, the word of the Father. Ile was conceived and born without seed, was manifeuted on carth, and walked among men, to free frem the folly of polytheism those men who belicve in him; and, having perfected all for which he was scnt by the Father, and having suffered the cross and dcath of his own free will, he was buried in the tomb; he plundered Ilell, and broke the power of Salan, and freed the imprisoned spirits from their londs, and raised them in the glory of Ilis Father into Ileaven. And Ile sat down on the right hand on high, and sent down unto his disciples the IIoly Spirit, his fellow being, the fellow-sharer of the father's glory, and the Comfurter. And they, having been flled with the Iloly Spirit, preached to all the heathen, baptism of Father, Son, and 1loly Spirit, and taught all men to keep his commandments. And this is the command and code of Jesus Christ. Iurity of nind, holiness of woul, pity for the poor, love of neighbours, humanity towards brethren; to exchew evil and follow the gool, to do good to enemies; fasting, and prayer, and pity for the poor; not to fornicate, or rob, or slay, nor lic, nor bear false nitness; but to live in truth, love God and your neighbour sincerely; to 
honour father and mother, ponder the law of God, and abide in his command. ments, be right in faith and good in works, holy-minded, pure in spirit, and single-hearted, and unflinching in love.

"This is the law of the faith of Christ. Know, $O \mathrm{king}$, that the true God is Jesus Christ, son of the Iloly Virgin Mary, crucified by the Jews. And his commandments are true and there is no other god but he."

The Armenian Barlaam and Josaphat ends as follows:

And after that Josaphat spent in the wilderness thirty-five years. But when he withdrew from his kingdom he was twenty-five years old. And thus he lived a life pleasing to God and did not depart from the cave of Baralam until his death. But after his transition from this life, some of the neighbouring brethren of the descrt [by intimation from the spirit] came and buried the [holy] loody of Jovasaph, near to Baralam's. And Bavakia the king, having heard [thereo[], sent priests and monks; and [having opened the tomb of the saint] they found the flesh of the blessed ones uncorrupted. And with great honour they took and carricd them to India [as it was near, a journcy of one day]. The king bavakias [went out to mect them with all his magnates and a multitude of the common people]. [And as was befitting they brougbe him into his paternal kinglom, and laid him beside $\Lambda$ bener the king.]

And to this day God worketh many wonders by the prayers of those [who arc] of the land of India.

The which even I Asat, a sinful scrvant of God, with much labour and toil, and here and there' summartsing it, translated into the Armenian tongue, by the help of an honourable prince. Wherefore by means of their self-slenial and life of grace, the IInly Trinily is glorified, Father, Son, and IIdy Chost, now and crer.

The Greck text of Barlaam and Josaphat was first printed in Boissonade's Ancedota, Paris 1832 ; and his text is re. printed in Migne's Patrologia Graca. Most of the Greek MSS. ascribe it to Jolin of Damascus. Others name John the Monk, an honourable and virtuous member of the monas. tery of Mar Saba, near Jerusalem, as the person who brought this edifying history from the interior of the land of the Ethiopians, called the Indians. The Greck narrator professes to have gathered his narrative from the lips of respectable persons, who faithfully handed it on to him. But a few Greck MSS. (c.g. MIS. 137 of the Bibliotheca

' Or, and making it little out of much by summarising it. 
Naniana, of the eleventh century), as also a Paris MS., attest in the title that the history, so brought to the holy city by John the Monk, had been translated into Greek from the language of the Iberians by Euthymius, an honourable and pious Ibcrian.

Now of this Euthymius we know a good deal from native lberian or Georgian sources. He died 1027, having been abbot of a convent on Mount Athos, where is still preserved his recension of the Georgian Bible in a MS. perhaps copied by him with his own hand.

Of the Greek text of Barlaam and Josaphat there is an Arabic translation, of which MSS. are found written as carly as the $13^{\text {th }}$ century. The Ethiopic version, according to Zotenberg, was made from this $A$ rabic version.

But besides this Christian Arabic version, there is a very old non-Christian recension of the tale in the same language, which was translated early in the $13^{\text {th }}$ century into Hebrew, under the title "Priest and Dervish." This Hebrew form Dr. Nathan Weisslovits and Professor Fritz Hommel have translated and compared with the Greek. The first half of the Arabic text, on which the Ilebrew is based, was first published by Hommel in the proceedings of the VIIth Oriental Congress at Vienna (Semit. Sect. pp. 115-165). Rehatzek has translated it into English in the Journal of the Royal Asiatic Society (N.S. xxii., 1 10-155).

Now this non-Christian Arabic form differs in essential respects from the Greek. Firstly, all the Christian reflections and teachings which form the bulk of the Greek text are of course absent. But secondly, what is more important is this, that the apologues or parables follow one another in it in a different order from that in which they are given in the Greck. Thirdly, the text also of these apologues presents in this $\Lambda$ rabic form marked diversities from the Greck, as also the chronology of the lives of the ascetics.

1 Rrint and Derwisch. Munchen, 18 ģo.

vot. vit. 
The problem of the immediate textual parentage of the Greek form secmed to have suddenly been solved, when in 1888 Professor Marr of the St. Petersburg University published, in the proceedings of the Russian Archacological Society, scveral extracts from the old Georgian text itsclf, along with a general description of its nature and contents. This Georgian version must be of great agc, for it is ivritten in the good and pure idiom of the Georgian N.T. which belongs to the fifth century; though that it is later than the Georgian N.T., the citatious therefrom inbedded in it prove.

P'rofessor Ilommel of München and Baron von Rosen, a Russian scholar, jumped to the conclusion that in this Georgian text we have the immediate parent of the Greck text, and that the notice found in two of the oldest Greck MSS.,-that Euthymius translated it from Georgian,-is actually true. But, as Kuhn in his elaborate monographion Barlaam and Josaphat (published in München, 1894 ,) points out, this view is untenable. The attack on the iconoclasts, which the Greek text alone contains, belongs rather to the cighth century than to the last half of the tenth, in which Euthymius lived. The discovery also of such an carly document as the Apology of Aristides imbedded in the Greck text obliges us to throw back its date as much as possible. Lastly, the circumstance that the order of the apologues and the general outline of events in the Georgian disagrecs with that of the Greck, and follows the nonChristian Arabic and Pehlevi tradition, makes in the highest degree improbable this supposition of Hommel and Baron von Rosen. It is likely, I think, that the sentence in the Greck titles on which it is based were the addition of an lberian copyist in a Greek monastery at Athos, who was familiar with the story in his own tonguc. That Ibcrian monks often wrote out Greck books is likely cnough, and

' Cf. Kirumbacher, Ceschichle dir Byaans. Lileralur, p. 467. 
the paging of old Greek MISS. is sometimes in lberian letters. This is the case with the early eighth century paging of the new Sinaitic palimpsest of the Gospels lately found at Sinai by Mrs. Lewis, and in the Bodleian there is a ninth century codex of the Gospels, also paged with Iberian letters. This much only is certain, that the Georgian text gives us a very primitive form of the legend; but, though a Christianised form, it cannot be a very direct ancestor of the Greck.

Now let us turn to the Armenian text. At first sight this appears to be nothing more than an abridgement of Boissonade's Greek text; especially as the Armenian translator asserts that he abridged his original. It has been accordingly set down by Kuhn and Zotenberg, who, however, had both of them a very slender knowledge of its contents, as a mere translation from the Greek. But I have now to point out many objections to this view.

Firstly, there occur in it purely Syriac words, like kasliath, in the sense of deficicitia. And the constant use of the participle for the finite verb is another indication that it was made from Syriac. Thus the existence of a Syriac form of the text, which Zotenberg ${ }^{1}$ denies to have been likely or possible, scems to be proved.

Was then the Syriac, of which the Armenian is an abridged translation, itsclf a version from the Greck as wc have it to-day? This is at the first glance improbable. The com. pilation of the Greck cannot be much earlicr than 750. It is possible, but unlikely, that it would have been turned into Syriac and translated again into Armenian at so carly a date as 950, much later than which date the Armenian cannot be.

Such reasoning is of course insecure. When, however, we observe that the Armenian, abridged though it be from a longer text, has yet many additions and peculiaritics not

1 Notices et Extraits, vol. 28, p. 79. 
present in the Greck, yet found in the non-Christian Arabic and Hebrew, and cren in the Georgian forms, then it becomes impossible to suppose that it is a mere abridgement of Boissonade's Greek text. Let us take some examples.

The Greek text of the apologue of the man pursued into a well or ditch begins as follows: "Those then who serve such a harsh and wicked master, severing themselves in their madness from goodness and kindness, and agape for present things and cleaving thercunto, never taking thought for the future, but pressing on unceasingly to bodily enjoyments, while they leave their souls to starve and famish and to be amicted with a thousand ills, these I consider to be like unto a man flecing from the presence of an infuriated unicorn," \&ec.

Now the Armenian has simply as follows:-"The life of this world is to be likened to a man flecing from the presence of an unicorn;" and this is very close to the Georgian: "This worldly life is like to a man whom an clephant pursued," \&c.

Then again in the Greek, the man in falling into the ditch stretched out his hands, and having caught hold of a certain tree (or plant) held it tightly. But the Armenian says he caught hold of the branch of a tree, which grewo on the edge of the pit? How did the $\Lambda$ rmenian know (t) that it was a branch to which he clung, and (2) that the tree greso on the cige of the pit. IVe turn to the non-Christian Arabic and there we read that he hung on to two branches that grew on its (i.e. the well's) margin.

It may be noticed that the Christian Arabic, which Zoten. berg shows to be in the main a translation of Boissonade's Greck, also adds the words: "which grew on the margin or cdge"; whence Weisslovits (Prins u. Derwisch) infers that its translator knew of the carlier $\Lambda$ rabic form and was in. nuenced by it in making his translation. $\Lambda$ simpler expla. nation would be that some older Greck text translated by the Christian $\Lambda$ rab included these words, and that they have dropt out of our cxisting Greck texts. And this hypothesis 
would cqually cxplain their presence in the Armenian, if this were an isolated addition. But as we find many similar additions in the Armenian we must reject it. Here is another cxample from the parable of the four boxes. In the Greck we read that the king closed the caskets containing the stinking bones of dead animals with golden clasps; while he bound round the pitch-besmeared box with ropes of hair. That exactly this detail is omitted both by the Armenian and by the old Arabic and Hebrew forms of the apologue can be no accident, because another detail in the story, namely that when the golden boxes were opened the magnates fled from the horrible stench, is omitted in the Greck, whereas the Armenian and the old Arabic and llebrew forms agree in retaining it.

Again, in the apologue of the hunter and the bird the Armenian relates, that when the hunter let it go, the sparrow flew away and perched on a bough and then began to soar in the air. Now in the Greek text nothing is said about the bird's perching on a bough (Rehatzek, p. 148 ); but in the old Arabic text we read: "Then he let go the bird, which flew azvay and perched on a branch." It may also be noticed that in the Arabic and Armenian the bird is a sparrow, in the Greek a nightingale.

Again, carly in the tale we read in the Greek that on the birthday festival of the newly-born heir there came together to the king about 50 picked men who had studied the stargaxing wisdom of the Chaldees. But the Armenian says: "he brought together $50 \mathrm{men}$ who were astrologers and wise men." Here the Georgian also has: "He called together the multitude of astrologers and of philosophers and of magicians." In the old $\Lambda$ rabic we read that the king "brought together the astrologers and the U'lama," which best reflects the Armenian. Like the Greck, the Armenian specifies that there were 50 of them, and then goes on to agrec with the Arabic and Georgian in its description of them. Onc turns with curiosity to the specch of Nachovr in 
the Armenian, because in the Greck form the whole $A$ pology of $\Lambda$ ristides is put into his mouth (Boisson. 241 If). The Armenian certainly follows the Greck text of this Apology rather that the independent Syriac text of the Apology itself which Professor R. Harris discovered in Sinai. It of course curtails it to a tenth of its length; but it also adds some particulars not in the Greck, and presents some of the arguments in more methodical and raisonné manner. Here is an example of such addition.

"I pass by the (supcrstitions) of the Hellenes and of the Egyptians and of the Chaldaeans, who instead of the immortal God worshipped men and women, harlots and Sodomites, and all other kinds of evil doers; yea, and the rat and the weasel and all sorts of vermin."

Now the above is ultimately a translation of some Greck text which began $\sigma \iota \omega \pi \hat{\alpha} \tau \hat{d} \tau \hat{\omega} \nu^{\prime} \mathrm{E} \lambda \lambda \eta_{\eta} \nu \omega \nu$. This rhetorical phrase docs not occur in the Greck, yet it is a familiar one in carly Christian apologies, and was certainly not inserted by the Armenian de suo.

Still less can the mention of the worship of rats and weasels be a mere addition by the Armenian translator; yet nothing of the kind is found in Boissonade's Greck. But in The Preaching of Peter we have reference to the folly of the Hellenes who worshipped weasels and mice ( $y a \lambda$ âs te kal $\mu \hat{v}){ }^{1}$ It is noteworthy that Professor Armitage Robinson 2 has already pointed out that Aristides' Apology was largely based on this very Preaching of Peter, of which we have only a few fragments left. 3 We must then suppose that the Armenian abridged his form of Barlaam and Josaphat from a text which not only included the Apology of Aristides,

1 Aput Clem. Al, Strom., vi. 39 n

- Apol. Aristides, p. 87, cd. pr.

- "Several passages of the Syriac version (of Aristides) which are wanting In the Greek, as we now have it, are authenticated by their similarity to

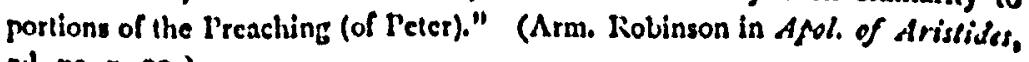
cd. pr. p. po.) 
but included it in a more complete form than our existing Greck MSS. of Barlaam and Josaphat. The sections of the Armenian directed against the worship of water and of mere men also strike me as better put and arranged than the corresponding scctions of the Greck text, though it must be owned that the latter, so far as it here varies from the Armenian, is in general endorsed by the Syriac form of the Apology, which is a document quite independent of the Book of Barlaam and Fosaphat.

Now no single clue of this kind would be enough to cstablish the independence of the Armenian, and its priority to Boissonade's Greek text, in the cyes of anyone who considers how closely allied in general are these two forms of text, if contrasted with the non-Christian Arabic, and even with the Georgian. But an entire series of such clucs occurring together forbids us to regard the Armenian as an abridgement of our existing Greek text. Yet abridgement of some text it certainly is, and of one very closely similar to Boissonade's Greek. This text we have seen was a Syriac one; and in this Syriac text, now lost, we must perforce recognise an carlier stage of the text than Boissonadc's Greck supplies. The Syriac was probably much shorter and less padded out with disquisitions on all points of Christian faith and morals. But in it the apologues had alrcady assumed the order in which they follow in the Armenian and Greek; and it must have contained cverything which the Greek and Armenian have in common. This Syriac text was, I am inclined to think, itself a translation of a Greek text, now lost, which was subsequently expanded into Boissonade's text. Boissonade's text was claborated out of this carlier and shorter Greck form, by some onc who frecly expanded it and substituted cverywhere for its simpler phrases the rhetorical flourishes of a later age. If this be a correct view, our existing Greek text of the Apology of Aristides must be :regarded with some suspicion. Such an apology had already of course a place in 
the shorter and earlier Greek text, which was rendered into Syriac and only survives in the Armenian abridgement. But who knows what changes this apology may not have undergone at the hands of the author of our existing Greek. The $\Lambda$ rmenian proves that some characteristic touches borrowed from The Preaching of Peter were obliterated when the carlicr Greek was worked up into its existing form.

Till we have the complete Georgian text before us, it is rash to be too positive about its exact place in the development of the Christian form of the legend. But it is clear from Marr's account of it, as also from his printed excerpts which I have translated, that it had much in common with the simpler Armenian text. This is seen if we compare the forms of creed given in the Georgian and Armenian with the corresponding passage in the Greek (Boissonade, 83-84). In the old Arabic and Hebrew texts there is of course no corresponding passage, no counterpart at all. So a long extract from the Georgian about design in nature is closely similar to the Greek text, while the old Arabic form has barely the rudiments of the argument, which the Armenian omits altogether. Indeed, a careful comparison of the Greek and Georgian reveals that they have many points in common, which are absent from the old Arabic and $\Lambda$ rmenian, though this last fact lias little significance, as the Armenian is a confessedly abridged text.

We must recognise, then, that already in the Georgian text, in spite of its comparative nearness to the nonChristian forms of the legend, evinced by its arrangement of matter and spelling of the proper names, the development of the latest Christian text as revealed in the Armenian and Greck has begun and cven made fair progress. It cannot be regarded then as a Christianised form of the legend in. dependent of the common parent of the Syrian, Armenian, and Greck texts, but must take its place far back in their common pedigree as the carliest stage of the Christian development of the tale. Next alter it, longo sed proximus 
intervallo, in the line of Christian tradition came an hypothetical Greck original of the lost Syriac text, of which our Armenian text is an abridgement. Of it the existing Greck text is a rhetorical expansion, made in the eighth century.

There is some ground for supposing that even tlie socalled non-Christian Arabic form translated by Rehatsek has been influenced by Christianity. For example, it contains the Christian apologue of the Sower; as well as a reference to the folly of worshipping idols which had to be locked up to prevent their being stolen. This last is a commonplace in carly Greek apologies of monotheism, whether Jewish or Christian, and may very likely have had a place in The Prcaching of Peter. But, however that may $b e$, the evidence of the Georgian and Armenian texts proves that Boissonade's Greek text (i.e. the eighth century form of the story, commonly but wrongly ascribed to John of Damascus) is a very late development. I think there was once a simple and brief Christian and Greek form of the text, of which the Georgian is a translation either direct or indirect. This carliest Greck form probably originated in Bactria in the third century A.D., in circles in which the religions of Jesus and Buddha met and mingled. I cannot otherwise explain the fact that the Georgian is often a literal rçndering of our Greek text. This earlicst Greek form set the apologues in the same order in which the Georgian and non-Christian Arabic has them; it followed the chronulogy of these texts, and, like the Georgian, had not yet the Apology of Aristides. For Professor Marr implies that the Georgian docs not contain this apology.

The ncxt stage in the growth of the Greek text was that which we have in the Armenian. In it the Greek nearly assumed its present form; the order of the apologues was changed; and the Apology of Aristides, with other cdificatory matter, was added. $\Lambda$ this stage the Greek passed into Syriac, and thence into the Armenian abridgement. 
The third and last stage of the Greek is that which remains to us in Boissonade's Anecdoton. In it new matter, like the attack on the iconoclasts, was added; and the $A$ pology of $\Lambda$ ristides lost in it some of the authentic touches which the Armenian representative of the earlier stage still echoed. The Christian Arabic is a version of this fully developed Greck form. So according to Zotenberg and Kuhn is the Ethiopic; though I do not myself feel sure that the Ethiopic will not be fuund to represent an earlier stage of the Greck. It is possible also that some of the Latin texts may prescrve the older Greck forms. With a view to recovering the Aristides Apology in an authentic form, the Ethiopic and Latin texts of the story should be examined; and scarch made for the lost Syriac form so imperfectly represented by the Armenian. It is even certain that the $\Lambda$ rmenian text, as it survives to us in $\Lambda$ rakhel's poem and in the Menologia, has becn mutilated. For in the so-called Gcography of Vartan, a work of about A.D. 1300, the Indian city of Sinavathan is mentioned as the seat of the kings of India, where $A$ bener and Jovasaph dwelt. But the cxisting Armenian text has lost this detail.

\section{FOLKLORE FIRSTFRUITS FROMI LESBOS.}

bY W. II. D. ROUSE, M.A.

(Read at Mecting of 17 th Deccmber, 1895.)

The following notes were collected, partly from my own observation and questioning of mulctcers and all sorts of odd pcople, partly from Mr. Stavros, schoolmaster of Kalloni, in Lesbos. I have to express my warm thanks to Mr. IV. R. Paton for constant help while in the island. What I 